\title{
On the genetic kinship of the languages Tikúna and Yurí
}

\author{
Fernando Orphão de Carvalho ${ }^{1}$
}

\section{Resumo}

A proposta de relação genética entre a língua Tikúna, atualmente considerada como uma língua isolada, e a já extinta língua Yurí é analisada aqui de forma mais sistemática do que se encontra na literatura publicada. Nossa conclusão é de que as evidências de um grupo Yurí-Tikúna foram subestimadas e que se configuram como um forte indício de relação genética. Subsidiariamente, este artigo pretende expor de forma condensada as propostas já elaboradas de classificação genética da língua Tikúna.

Palavras-chave: Classificação linguística, filiação genética, Tikúna, Yurí, línguas isoladas.

\begin{abstract}
We subject the hypothesis that Tikúna - nowadays considered an isolated language - is related to the now extinct Yurí language to a more systematic analysis than one finds anywhere else in the published literature. We conclude that the evidence for the Yurí-Tikúna group has been underappreciated and that it points strongly to a genetic connection. The subsidiary goal of this paper is to stand as a condensed statement of the proposals already made for the genetic classification of the Tikúna language.
\end{abstract}

Keywords: Language classification, genetic affiliation, Tikúna, Yurí, linguistic isolates.

\section{Introduction and General Considerations ${ }^{2}$}

The linguistic landscape of South America forms a bewildering scenario and offers formidable problems for the historical linguist. Added to the fact that the New World harbors more diversity of language groups than any of the other four continents (Nettle 1999, Campbell 1997), the scattered and interwoven distribution of such units as well as the large number of language isolates makes this landmass a unique testing ground for the methods of detecting and justifying claims of common ancestry among languages (Campbell 1997, Dixon \& Aikhenvald 1999). It's not an accident that some of the most bitter (and informative) debates on the nature and the foundations of historical linguistics have been motivated by the evaluation of claims concerning the genetic or historical relations among South American languages (Adelaar 1989, Campbell 1997, Matisoff 1990, Rankin 1992).

\footnotetext{
${ }^{1}$ Mestrando em Linguística, Laboratório de Línguas Indígenas (LALI), Universidade de Brasília.

${ }^{2}$ I am thankful to Aryon D. Rodrigues and Ana Suelly Arruda Câmara Cabral for their comments and stimulation for publishing this paper. I am also thankfull for the comments by two reviwers.
} 
Though not discussed in detail by the reference works of NorthAmerican or European researchers, the Tikúna language fits well in this scenario, being one among other 'linguistic islands' of single languages or small families intermingled with members of larger, continent-wide groups such as Arawák, Tupí, Karíb or the Quechua 'dialectal continuum'. After a brief presentation of the language, we'll start having a closer look at the nature of the problem concerning the linguistic relations of Tikúna, focusing on particular claims in a more detailed manner and contributing with a few suggestions, highlighting some patterns or sets of data that have been either unnoticed or not been given the deserved attention in the relevant literature.

Special attention will be directed, throughout the presentation, to the hypothesis that Tikúna is related to the now extinct Yurí language, a hypothesis qualified as 'promising' in the reference works of investigators of the historical linguistics of South America (cf. Campbell 1997:184) though never subjected to closer scrutiny.

\section{The Tikúna language}

The Tikúna language is spoken by some 40.000 individuals living in the Brazilian, Peruvian and Colombian Amazon, with the largest population densities in the upper Solimões region, including the Içá and Japurá rivers. Tikúna speakers can be found, however, almost anywhere from the periphery of Manaus in Brazil upstream to Iquitos in Peru.

The language has figured in a more or less prominent position in the typological literature as having a complex tonal system with five tone levels in its underlying phonological representations (cf. Maddieson 2005:58-61). The original sources in which these claims are made (Anderson 1959) however, hardly deliver any evidence supporting such a claim (the work is actually a quite confuse mix of phonetic description and attempted phonological analysis; cf. Rodríguez 1995:25-26 for a similar assessment). Actually, the language seems to have an opposition between three underlying tonal specifications: low, middle and high (Rodríguez 1995, Soares 1998, Wise 1999:318).

The segmental phonology of the language isn't extraordinary or especially marked in any obvious sense. There are three places, bilabial, coronal and dorso-velar for stops, a voice opposition with no gaps, as well as voiced and voiceless alveo-palatal affricates. The language has also one coronal continuant (a flap) and a labio-velar approximant $/ \mathrm{w} /$. The status of the three phonetic nasal consonants matching in place the stops is more 
uncertain, with dialectal factors also playing a role in the evaluation of claims of phonological constituency (cf. Soares 1986, 1995; Rodríguez 2004).

As it regards the vowel inventory, there's pretty much an agreement on the existence of six vowel qualities for oral vowels (/i e a u o $\dot{i} /)$ with a corresponding, matched set of phonemic nasal vowels. Beyond that there's some lingering uncertainty on the existence of laryngealized vowels and simultaneously nasal-laryngealized vowels, again with dialectal differences playing a role in this regard (Rodríguez 2004, Soares 1986, 1995:201). It should be kept in mind though, that much remains obscure concerning the finer-grained arrangement of Tikúna sound structure. A preliminary acoustic phonetic description of the language is being currently devised by the author, building in part on the pioneering work of Soares (1984).

In terms of morphosyntactic typology, Tikúna is a mixed head- and dependent-marking language, with $\mathrm{OV}$ as its main constituent order and showing subject and object markers on the verb as well as case marking on nouns (Soares 1992). The morphology is closer to an agglutinative type, showing few elements of fusion or internal sandhi. There are up to two or three prefix positions on the verb, a more definite statement on this regard depending on the clitic versus affix status of certain formatives. Nevertheless, the language seems to be mostly suffixing. The language also has processes of noun incorporation (Rodríguez 2004).

\section{The singularity of Tikúna: a first approach}

Nowadays, the Tikúna language is taken to be a genetic isolate, not related to any other isolate or language family in the Western Amazon region where most Tikúna speakers now reside. Some of these neighboring linguistic families include:

$\begin{array}{cc}\text { Záparo } & \text { Witoto } \\ \text { Iquito } & \text { Bora } \\ \text { Arabela } & \text { Muinane } \\ \text { Záparo } & \text { Miraña } \\ \text { Katukina } & \text { Makú } \\ \text { Katukina } & \text { Dâw } \\ \text { Kanamarí } & \text { Hupda } \\ \text { Yuhup } & \text { Kakua } \\ & \text { Nadëb } \\ & \text { Nukak }\end{array}$


Pano

Mayoruna

Marubo

Tukano

Orejón

Tanimuca

Isolates or non-classifiable languages

Andoke

Muniche
Arawak

Kauyxana

Resígaro

Barasano

When we look at the structure of Tikúna, several similarities with the above-mentioned languages may be observed, as well as striking differences, in both grammar and lexicon, which seem to preclude any attempt at establishing claims for genetic relationship. In the case of living languages at least such hypotheses can be tested by painstaking research. For those families where lack of adequate documentation prevents the reconstruction of proto-languages, or for the poorly described isolates, the prospects for any constructive work evaluating claims of genetic relationship are rather dim.

In terms of general typological similarities with the neighboring languages mentioned above, no clear pattern that could point to a genetic connection can be unraveled. If on the one hand Tikúna shares with Makú, Witoto, Yagua and Tukano languages the phonological use of tone at the level of the word or the syllable (as pitch-accent systems or as 'true' tone languages), this evidence is weak. Tonal contrasts are known to be easily diffusible in other regions of the world (cf. Matisoff 1999) and in Western Amazon itself we have the case of Resígaro, an Arawak language which acquired tone under Witotoan influence (Aikhenvald 1999: 74, 79; Ramirez 2001:391) with the further possibility that tonogenesis in the Makú family may be the result of long-term contact with speakers of Tukano languages (Martins \& Martins 1999:254-256).

In the segmental phonological inventory the picture is also rather messy: though Yagua, Bora and Muinane (Witoto) and Proto-Tukano all have a six-vowel system similar to Tikúna, as well as tones (cf. Malone 1987; Wise 1999:316), Bora has an aspiration contrast for stops and affricates, as 
well as two fricative phonemes (Thiessen 1996); the Muinane language has an opposition between palatalized and plain stops (Walton \& Walton 1967). Yagua differs from Tikúna in having a glottal fricative phoneme and in allowing for complex consonant clusters (Wise 1999:315). Anyway, Yagua is the sole language among these for which we have independent evidence of contact with the Tikúna (Tessmann 1930:559, Rodríguez 1995:19).

The scenario emerging from a comparison of morphosyntactic patterns is also not illuminating in revealing patterns that may point to any clustering of these languages which would both include Tikúna and point to similarity possibly brought about by common ancestry (cf. Rodríguez 2004:170-173). Any hope then of demonstrating a genetic relation in western Amazon that includes Tikúna cannot stand even as an 'informed guess', unless one starts a careful organization and analysis of the relevant evidence aiming at an application of the tools of the comparative method.

\subsection{The Yurí-Tikúna Hypothesis}

An underlying and recurring theme in the present work is the hypothesis that the Tikúna language may be genetically related to Yurí, an extinct language on which a few wordlists are available from XIX century explorers and ethnographers such as Johann Baptist von Spix, Carl Friedrich Philip von Martius, and Alfred Russel Wallace (cf. Martius 1867, who mentions that the language was also known as 'Tukano-Tapuya', Wallace 1853). If, on the one hand, it is not true that all researchers who have tried to fit the Tikúna language in some classification scheme have grouped it in any special way along with Yurí, it is true that this is by far the most promising hypothesis on Tikúna genetic relationships ever proposed (cf. Campbell 1997:184). As we'll show though, it is a hypothesis that has never received its due share of attention. What we purpose to do here, besides reviewing and condensing in a single place the several attempts to relate the Tikúna language to other languages or families, is to fill this gap and subject this hypothesis to careful analysis.

The most obvious problem plaguing any attempt to deal with the Yurí data is the fact that Yurí is, by all accounts, an extinct language on which a very small sample of lexical information collected by amateurs is the sole material. In spite of their unique contributions to the ethnographic knowledge of native South American peoples, the linguistic data provided by Spix, Martius and Wallace are usually of low quality, especially when contrasted 
to much more careful transcriptions such as those of Curt Nimuendajú or Constant Tastevin, who in turn, have no first hand data on the Yurí language (cf. Ramirez's 2001:21 assessment of the Spix, Martius and Wallace data on northern Arawak languages).

Unless indicated otherwise, all the Tikúna data presented in the following analyses is from the author's own fieldwork, carried mostly with speakers from the 'Ticuna de Santo Antônio' reservation near Benjamin Constant, Amazonas, Brazil (june-july 2009) as well as from his 2-year long interaction with a Tikúna family living in Brasília. The Tikúna lexical items were, nevertheless, checked with those given in the descriptive literature on the language (cf. Anderson 1958; Rodríguez 1995, 2004; Soares 1986, 1995) with no striking differences being noticed.

\section{Presentation and Review of Claims for Genetic Affiliation}

\subsection{Constant Tastevin's (1921) Yucuna-Uri-Ticuna}

As a first observation we should note that the Duri or Uri language whose lexicon was sampled by Constant Tastevin (1921) does not seem to be the same language as the Yuri (or Juri) language that has been claimed to bear a special relation to Tikúna and which is known by the lexical material presented by Martius (1867:268-272) (cf. Nimuendajú 1952:156 and section 3.3.2 for the claim that there are "common elements" in both languages, Greenberg 1987: 93 for a claim of genetic relation). Their similar names and the fact that Tastevin presents the Uri data in the same table as he presents his Tikúna data, may lead to confusion. A list comparing the Yurí of Martius (1867) and Tastevin's (1921) Uri is shown below:

\section{Martius' Yurí (1867)}

Fire ji (M); yy (S); ii (W)

Tooth cho-öta

Mouth (tcho) iá (W); tschu-ijägh (M); suya (S)

Nail su-pêty (S)

He Niy

She Niy

I tschu-, tschö-, tschä-, tscho-

You wikú (M)
Tastevin's Uri (1921)

pilö, pihörö

gópaika

gohpaka, dyákopẹ

múhungáti

Ígö

Íga

dyöö

mốö 
Tastevin himself seems to have recognized the difference between the two languages (Tastevin 1921:482-483). He also noted similarities between both languages and Tikúna, taking the care to postulate resemblances in basic vocabulary. He gave special attention to the similarity in the forms of the first-person pronoun. Tastevin also observed that the lexicon of animal names of Yurí was basically of Arawak origin, while that o Uri has close similarities to their correspondents in Tukano languages. He didn't remark, though, the close resemblance (one could say, virtual identity) between the pronoun forms of Urí and those found in Tukáno languages such as Desano and Cubeo (cf. Mountain 1978) ${ }^{3}$.

Although some investigators seem to propose that Uri was a variant or dialect of the Yuri language (cf. Rodríguez 1996:83) a comparison of the forms above seems to speak against such a hypothesis.

\subsection{Günter Tessmann's Die Indianer Nordost-Perus (1930)}

In his book on the anthropology (Kulturkunde) of the Indian groups of Northeastern Peru, Tessmann presented a curious system for classifying languages (his Sprachliche Verwandschaft) which couldn't easily distinguish contact-induced influences from similarities resulting from common ancestry.

His method consisted in marking as 'points' (punkte) each 'word' for a given language which seemed as an 'element' from one of the 7 major language groups he recognized (Tupí, Jê, Arawák, Pano, Tukáno, Karíb and Quechua 1930:617-624). The classification was carried by comparing a 33item list (vergleichswörter) organized for each language and counting the number of 'elements' (1930:624). So, for example, the Omágua language was classified along with Kokáma in a purely Tupí group (reiner Stamm) for they had 25 word forms that looked like "Tupí elements". The Mayoruna language, on the other hand, was classified as belonging into one of several mixed groups (Mischstämme:Arowaken-Tupi) wih an Arawák base (10 elements) but with a significant number of Tupí elements (7 elements).

As it concerns Tikúna, Tessmann's classification is basically correct as far as our current understanding goes. He considered Tikúna as a member of one of his two isolated groups (isolierte Stämme) but with recognizable elements of Arawák, Tupí, Tukáno and Karíb origin. One counts 22 'elements' for Tikúna (1930:626), 11 less than the 33-item list of Tikúna word forms used for comparison (the latter with 5 items less than the 38-item list or

\footnotetext{
${ }^{3}$ This fact was pointed out to me by Marcelo Jolkesky, personal communication.
} 
sprachproben presented for Tikúna at page 564 of the same work). No data on the Yurí language is presented by Tessmann, though the author recognized the existence of a "Yuría oder Yur'" group living southeast from the Bora and near the Brazilian-Colombian border (1930:584).

\subsection{Curt Nimuendajú's The Tukuna (1952)}

In the second appendix of his major ethnographic monograph on the Tikúna, Nimuendajú includes several comments on previous claims of genetic affiliation or language contact involving other, independently recognized groups and the Tikúna language.

He criticizes Rivet's claim that Tikúna belongs into the Arawák stock ("un dialecte Arawak très corrompu") showing that the similarities presented in Rivet (1912) are based on deficient phonetic transcriptions of the Tikúna items, besides being superficial and overlooking obvious differences in morphological structuring between the compared items (1952:156). Nimuendajú observes, however, that there was probably a major influx of Arawák items into the Tikúna lexicon, and mentions Daniel Brinton and Günther Tessmann as earlier investigators who recognized such Arawák influence into Tikúna. Nimuendajú's analysis seems to be basically correct in this regard.

As for the obvious elements of Tupí origin in the Tikúna lexicon, Nimuendajú correctly observes that they are larger in number than Rivet supposes (1952:156). Nimuendajú cites the verb base meaning "to drink" as an example of a Tikúna item with a "Tupí equivalent". He presents the Tikúna form as $a \ddot{e}$ ' and the Tupí form as $a u$ ', with the added comment that in the Tupí form $a$ - is the first person pronominal prefix. It should be noted that Nimuendajú doesn't consider at any point as plausible the hypothesis that Tikúna is genetically related to Tupí, which is a sensible point methodologically given that he criticizes the disregard for morphological boundaries in Rivet's presentation of the hypothesis of genetic affiliation, but deems as possible the borrowing of the complex Tupí form $a u$ ' as a single Tikúna item ä̈', a situation commonly seen in diffusion of lexical material.

Nevertheless, the borrowing of such a basic vocabulary item as 'to drink' is rather unlike, for several reasons. The first reason is that even neighboring languages which borrowed extensively from Tupian languages, such as Kokama (cf. Cabral 1995) maintained their basic vocabulary (Kokama for example has kurata for 'to drink'). As a second reason, the Tikúna lexical 
items with an undeniable origin in the borrowing of items of Tupí origin or from the Língua Geral Amazônica are restricted to 'non-basic vocabulary' items. Representative examples of such obvious borrowings are (with tones omitted): [natfiru] "clothes"; [ui] "flour"; [tupana] "god"; [putíra] "flower"; [pitfana] "cat".

Nimuendajú mentions the existence of a 'Tukáno element' in Tikúna (as noticed by Tessmann; cf. section 3.1.) but regards it as very weak, citing Rivet as agreeing with this evaluation (1952:156). Neither Nimuendajú nor Tessmann show the data bearing on such putative Tukáno influence on Tikúna. Later on, Greenberg pointed out a few similarities involving a few items (cf. section 3.4.). A supposed lexical component of Múra origin proposed by Loukotka is dismissed by Nimuendajú (1952:156).

\subsubsection{Tikúna and "Jê" Languages}

From a contemporary perspective, one of the most curious claims for a 'linguistic relation' with Tikúna is the claim that there is a 'Jê element' (including Kamakã and Mashakalí material) as Nimuendajú puts it, consisting of some 16 lexical items identified by von Martius and later on by Paul Rivet. Nimuendajú promptly dismisses most of them as extremely vague or as comparisons that involve too large semantic latitudes. He retains a total of 5 similarities (with Kamakã, Timbira, Kayapó and Xerente) which he qualifies as 'not entirely fortuitous' but admits that "I can offer no acceptable explanation of them" (1952:157). Nimuendajú also dismisses the explanation given by Paul Rivet according to which Arawák languages would have borrowed some roots from Jê languages, with Tikúna eventually borrowing these same roots from Arawák languages.

Notwithstanding the generally and otherwise sensible arguments given by Nimuendajú, it seems fair to assume on linguistic grounds alone that these 5 remaining Tikúna-Jê similarities are fortuitous or accidental, at least for the following reasons:

(1) First of all, none of these similarities can be observed in other items of basic vocabulary and grammatical forms or show any systematic correspondences, which seems to preclude a hypothesis of common origin. The similarity between Tikúna para "leg" and Xerente pra "foot", given by Nimuendajú as one of the relevant resemblances (1952:157) isn't matched by similarities in the rest of the basic vocabulary, as shown by: 
Tikúna

a.) /na-mę/ "hand"

b.) /dgati/ "man"

c.) /

d.) /nori/ "his"

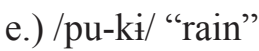

Xerente

da-nĩpkra "hand";

bamâ "man".

waĩtê "my";

tahã tê "his".

ta "rain"

(cf. Krieger \& Krieger 1994 for the Xerente forms).

(2) Besides that, if any of these Jê languages are closer to each other than any is to Tikúna (something that seems accepted by both Nimuendajú and Martius) then the methodologically sensible way to carry the comparative work is to compare Tikúna data with Proto-Jê data or at least with those forms reconstructed for a subgroup of Jê which includes all these languages. As in (1) above, a comparison of the Tikúna forms with those reconstructed for Proto-Jê (cf. Davis 1966) yields no evidence of a genetic relation:

Tikúna

a.) /na-pita/ "tooth"

b.) /na-dàò/ "to be red; ripe"

c.) $/ \mathrm{g}$ ibi/ "to eat"

d.) /na-nati/ "father"

e.) /dèá/ "water"
Proto-Jê

*cwa "tooth"

*ka-mrek "red"

*ku, kur "to eat"

*pan m "father"

*yo, yoc "water"

The similarities involve languages which are not as closely related as Nimuendajú may have thought. We now know that Kamakã actually belongs into a different family within the larger Macro-Jê stock while Xerente, Kayapó and Timbira are recognized as members of the Jê family (cf. Rodrigues 1986:56, 1999). This being so, it is not at all clear, if there is any genetic relation between Tikúna and Macro-Jê languages, why then the proposed similarities would be absent from other groups.

Nimuendajú concludes his presentation on the linguistic relationships of the Tikúna language saying that: "It is preferable to consider it, for the time being, as Chamberlain and Tessmann do, an isolated language." (1952:158). 


\subsubsection{Tikúna and Yurí}

Concerning the connection between Tikúna and Yurí, the author notices that "...the similarities with Yurí are fewer [than those with Tupí], but not less in importance." (1952:156).

The fact not highlighted by Nimuendajú is that, contrary to the data presented as probable borrowing from Tupí languages or from the Língua Geral Amazônica, most similarities between Tikúna and Yurí lexicons are found in pronoun forms and in basic vocabulary. We have examined the Yurí vocabulary given in Martius (1867:268-272) and we have selected the most likely candidates for cognate status for presentation below, along with the Tikúna equivalents:

Tikúna

(1) Man [dzati $]$

(2) Fire

[ipi]

(3) Lake/River [tàtí]

(4) Eye [tfaurti] 'my eye'; [cti] 'eye'

(5) Dead

(6) Head

[ḑù]

[t $\mathrm{fav \varepsilon ru]}$ 'my head'; [eru] 'head'

(7) Father [nati] 'father'

(8) Foot [t [arkūtí]'my foot'; [kūtí] 'foot'

(9) Mouth

(10) Child

(11) Fish

[’’ó] 'jijú fish’

(12) Long [ma]

(13) Sorcerer [ḑu?ú]

(14) Knee [tgavapi] 'my knee'; [api] 'knee'

(15) Tree [nai]
Yurí

tschoko (M); soku (S)

tchoucú (W)

ji (M); yy (S); ii (W)

thiättê (M)

tschu-äti (M); äti 'eye'

tsché (M)

tschu-gerühó (M); gerüho

'head'

hato $(\mathrm{M})$; háto $(\mathrm{W})$

tschu-óti (M); (tscho) u-óti

(W)

(tcho) iá (W); tschu-ijägh

(M); suya (S)

uhé

suabüe (S) 'daughter'

Oöó

mähä (M); maèe (S); meye

seyú

tschu-obo (M); suopo (S)

noinó (W) 


\begin{tabular}{|c|c|c|}
\hline (16) Nail & $\begin{array}{l}\text { [yaopati]'my nail'; } \\
\text { [pati] 'nail' }\end{array}$ & su-pêty (S) \\
\hline (17) Tooth & $\begin{array}{l}\text { [topita]'my tooth' } \\
\text { [pita] 'tooth' }\end{array}$ & cho-öta \\
\hline (18) Road/Path & [nama] & nemó (W) \\
\hline (19) Large & [tà] & tihi \\
\hline (20) To want & [tãyetfã̃] "I want; I miss (someone)" & tschanegottité \\
\hline (21) $\mathrm{He} / \mathrm{She}$ & $\begin{array}{l}\text { [ni-] '3 } 3^{\circ} \text { person' } \\
\text { [ni-ma] 'he kills' } \\
\text { [ni-déa] 'he speaks' }\end{array}$ & niy \\
\hline (22) You & [ku- ' ' $2^{\circ}$ person' & wikú (M) \\
\hline (23) I & $\begin{array}{l}{[\mathrm{tga}-],[\mathrm{t} \mathrm{i}-],[\mathrm{tgo}-]} \\
' 1^{\circ} \text { person' }\end{array}$ & tschu-, tschö-, tschä-, tscho- \\
\hline (24) Hammock & [napa] & nehipé (W) \\
\hline (25) Leaf & [naiàti] & nointjú \\
\hline
\end{tabular}

In the table above the Yurí data are from Martius (M), Spix (S) or Wallace (W) (cf. Martius 1867). The items lacking any of these indications are given as such by Martius. Item 17 was taken from the Yurí data given by Loukotka (1968:191).

A first step is to show that the items above show enough similarities in form and meaning and then look for systematic correspondences which may confirm their status as cognates. As it concerns the semantics of the items compared, the unique entries that seem in need of comment are 1 (Man), 3 (Lake/River), 11 (Fish) and 21 (He/She). In 1, the Martius and Spix items were given under the latin entry Homo, while the Wallace item was under vir. The Tikúna item is closer in meaning to the Wallace entry, meaning human male $^{4}$. In 3, the Martius item is labeled as meaning lac. Nevertheless, the Tikúna word [tàtí], nowadays usually applied to 'rivers' in general, is by many older speakers and in several contexts employed only as a reference to "the large river" (the Amazonas) and not to smaller water streams (cf. Nimuendajú 1929). As for 11, the Yurí term is given under the general meaning piscis, while the Tikúna item means one particular kind of fish. Item 21 is the most interesting of these. In the Yurí vocabulary given by Martius,

\footnotetext{
${ }^{4}$ In less conservative dialects it is used also for the male of some animals species (cf. Rodríguez 2004:61).
} 
the form nyi is given as meaning ille, a third-person masculine Latin form. The impossibility of giving a precise phonetic interpretation to this form is attenuated by the fact that Tikúna has masculine and feminine forms that do not seem quite different from the Yurí form: masculine $[n]]$, feminine [ni].

A few regularities can be observed in the data above, though we should keep in mind that specially as vowel sounds are concerned, the transcriptions of Martius, Spix and Wallace have been independently judged to be quite poor (cf. Ramirez 2001:21). With this in mind, all the putative correspondences sketched below should be judged with extreme care, and even more so when the context is specified in terms of vowel features. Hardly any comment will be made concerning particular vowel qualities.

As observed in the entries 3, 9, 10, 12 and 19, the von Martius transcriptions show reliably a sequence of vowel and $h$ or $g h$ when the similar Tikúna data show a creaky-voiced vowel (9 and 12), a low-tone (3 and 19) or a glottal stop (10). As it concerns the phonetic interpretation of such symbols in the Yurí forms, they may be either markers of a vowel property (such as a perceived guttural quality) or they may be independent segments. No clear answer to this problem could be found by analyzing the rest of the Yurí data or by comparing the three different transcriptions. In a few items the sequences of vowel and $h$ or $g h$ in the Martius items correspond to a grave accent mark in the Spix data (cf. 12), which could favor the former interpretation, but exceptions abound in the rest of the data.

When root initial, the oral [+grave] consonants in Tikúna correspond to zero in the Yurí data (cf. 8, 10). It may be the case that the nasal feature is actually irrelevant, given that in item 12 the correspondence Tikuna $m$ $\therefore m$ Yurí occurs in the context of non-back, unrounded vowels, while the correspondence Tikúna [+grave] : Yurí zero occurs in the context of back rounded vowels. Since these vowels too are characterized by a lowering of F2 and a concentration of energy in the lower parts of the spectrum (being then [+grave] too) it may be the case that [+grave] consonants disappeared from root-initial positions in Yurí since there was no pressure to maintain the marking of gravity in this position, given that the same spectral profile was marked in the vowels themselves. This hypothesis gains further evidence in its favor when items 16 and 17 are compared. In 16 the root initial [+grave] bilabial stop is retained in Yurí when it is followed by what seems to be an anterior vowel (the correspondence is $p: p$ ) and in 17 it is zero (that is, the correspondence is $p:$ zero). In items 1,14 and 22, the [+grave] consonants are retained even before back rounded vowels in the non-initial context. 
Tikuna $\{[+$ grave $],[-$ syllabic $]\}$ : zero Yurí / + _ $\{[+$ grave $],[+$ syllabic $]\}$

In the system of affricates, the Spix data give[s] $s$ for what Wallace and Martius transcribe as $t s c h$ - or $t c h$ - (cf. 1, 9, 14). The affricates in Yurí match those in Tikúna, with eventual mismatches in voicing (cf. 1, 5). As for item 12 , it is not clear whether $y$ stands for a voiced affricate [d] or a non-syllabic palatal vocoid. This latter interpretation assigning an "i-like" quality to this segment is favored by the Yurí data in 1 and 9. In either case a phonetic similarity can be assumed. On this regard it is important to note that Tikúna shows an alternation $\left[d_{3}\right] \sim[j]$ in the expression of $/ d_{b} /(\mathrm{cf}$. Lowe 1960).

Tikúna $t$ corresponds to Yurí $t$ with the sole exception of item 1 . Concerning the correspondence $t: t t$ in item 3 , it is a well known convention of German writting to employ geminate consonants to indicate that the preceding vowel is short, so that the $t: t$ correspondence isn't undermined by this item.

The nasal consonants of Tikúna all have corresponding nasals in the Yurí data, though a change of place of articulation is observed in item 20 (Tikúna $\eta: n$ Yurí). In item 7 there's a correspondence $n: h$ which seems to bring irregularity into the nasal correspondence set. However, it is well known that glottal and nasal features are associated in several sound systems, a particular instance of a phenomenon known as rhinoglottophilia (cf. Matisoff 1975). Thus, nasal consonants and glottal fricatives are not as different phonetically as one might be inclined to think. Though regularity and not phonetic similarity is the crucial feature of sound correspondences as a mean of demonstrating genetic relations, in the case of poorly transcribed, non-phonemicized material such as the Martius' wordlist for Yurí, such a demonstration that the material under comparison may be more similar than assumed from the start seems to count as a partial success.

Another interesting pattern of interaction involving the glottal fricatives, nasals and the stress system seems to obtain in the data. In the entries numbered 13 and 22, it seems that the Tikúna forms correspond to the stressed syllables of the Yurí forms. One could postulate the Yurí forms as the most conservative ones and that at a subsequent stage the unstressed syllables were lost, giving the pattern:

$$
\text { wikú }>[\mathrm{ku}] ; \text { seyú }>([\mathrm{d} \mathrm{u}]>[\mathrm{d} u \text { Pú }])
$$

What happens next is that the second-person marker $[k u]$ is kept as a monosyllable while the open-class item [dzupiu] is lengthened to match 
the prosodic weight of a binary foot. It is a well-known fact that, crosslinguistically, different conditions on optimal and minimal prosodic weight hold of open- and closed-class items ${ }^{5}$.

It seems to be the case that this putative process of weak syllable deletion shows an interaction between the nasal consonants and the glottal fricative $h$, besides the interaction implicit by the correspondence $n: h$ in item 7. Taking the acute marks (') as stress marks, we see that the forms in which the process of weak syllable deletion does not hold are the forms in which a nasal and/or a glottal fricative occurs in the first syllable $(9,10,15$, $18,24,25)$.

\subsection{McQuown's (1955) The Indigenous Languages of Latin America and Voegelin \& Voegelin's (1965) Languages of the World}

In his large-scale reference work on the language groups then recognized for the languages of South and Central America, Norman McQuown recognized both Yurí and Tikúna as separate, genetically isolated languages (McQuown 1955:541, 528). The same basic classification is put forward by Voegelin \& Voegelin (1965:149-150).

\subsection{Loukotka's (1968) Classification of South American Indian Languages}

This early reference work on the native languages of South America assigns Tikúna to the status of isolated language, with no clear relationship to any other language or linguistic family, thus agreeing with both Tessmann and Nimuendajú (Loukotka 1968:152-153). It is interesting to note that Loukotka sampled his Yurí data from the Martius 1867 list and still he didn't notice the highly suggestive similarities that we presented above.

Loukotka gives only a 12-item list of Tikúna 'words', presented in the same table as Peba and Yagua items with the same basic meanings. The Tikúna items which compose his list were probably taken, with minor typographic adjustments, from the larger, 38-item list given by Tessmann

\footnotetext{
${ }^{5}$ It could be pointed out that in the Tikúna forms given in the comparative table one sees open-class items which violate this prosodic weight constraint, such as 5 and 9, so that these would constitute evidence that no such constraint is at work in Tikúna. Nevertheless, if these constraints are taken to hold at the level of the prosodic word, then no problem arises, given that forms such as 5 and 9 never occur in actual utterances without prefixed inflectional markers which, in effect, build footlong phonological domains.
} 
(1930:564-565). Although Loukotka cites Alviano's (1944) work on Tikúna grammar and vocabulary, as well as Anderson's (1958) basic vocabulary, his decision of picking part of the Tessmann vocabulary for exposition is hardly understandable given the much more detailed transcriptions provided by Anderson (1958). We present below the 12-item Loukotka list with their corresponding items in the Tessmann, Alviano and Anderson vocabularies (N.A. indicates that the relevant items were not presented by the author):

$\begin{array}{lllll} & \text { Loukotka } & \text { Tessmann } & \text { Alviano } & \text { Anderson } \\ \text { Head } & \text { na-eró } & \text { naerō } & \text { na-erú } & \mathrm{na}^{2} \mathrm{e}^{4} \mathrm{ru}^{2} \\ \text { Tooth } & \text { ná-puita } & \text { nápuita } & \text { náputa } & \mathrm{na}^{3-5} \mathrm{pü}^{5} \mathrm{ta}^{5} \\ \text { Ear } & \text { na-chin } & \text { natšin } & \text { natchin-é } & \mathrm{na}^{2} \mathrm{chi}^{3} \mathrm{nü}^{3} \\ \text { Fire } & \text { öo } & \text { öo } & \text { N.A. } & \ddot{u ̈}^{4} \mathrm{xü}^{3} \\ \text { Sun } & \text { öake } & \text { öakë } & \text { Éáke } & \ddot{u ̈}^{3-5} \mathrm{a}^{5} \mathrm{cü}^{3} \\ \text { Earth } & \text { náni } & \text { nánii } & \text { ná-ne 'roça' } & \mathrm{na}^{3-5} \mathrm{a}^{5} \mathrm{ne}^{5} \\ \text { Man } & \text { yáte } & \text { yátë } & \text { Dját } & \mathrm{ya}^{3-5} \mathrm{tü}^{5} \\ \text { Tapir } & \text { náke } & \text { nákë } & \text { Nakê } & \mathrm{na}^{4} \mathrm{cü}^{3} \\ \text { Maize } & \text { cháwve } & \text { tšáwuë } & \text { N.A. } & \mathrm{cha}^{5} \mathrm{wü}^{2} \\ \text { One } & \text { wöi } & \text { wöí } & \text { Vuí } & \mathrm{wü}^{2} \mathrm{xi}^{2} \\ \text { Two } & \text { tádi } & \text { tádi } & \text { ta-aré } & \mathrm{ta}^{4} \mathrm{xre}^{2} \\ \text { Three } & \text { tamáipo } & \text { tamaípö } & \text { tamáepoe } & \text { to }^{3} \mathrm{ma}^{1} \mathrm{e}^{5} \mathrm{pü}^{5}\end{array}$

Two observations can be made from an inspection of the forms in the table above: the first is that Loukotka really took his Tikúna forms from a subset of the larger Tessmann list, with only a few typographic changes (Tessman's $[\mathrm{tš}]=$ Loukotka's $[\mathrm{ch}]$ ) and the second is that he supplied the relevant morphological boundaries when needed (i.e., in the body-parts items).

\subsection{Greenberg's (1987) Language in the Americas}

We are not going to deal in detail with the many and acute methodological shortcomings that undermine the claims for genetic relationship contained in Joseph Greenberg's book Language in the Americas (cf. Campbell 1988, Matisoff 1990, Rankin 1992). It is enough to stick here to the correct appreciation that Greenberg's method of 'multi-lateral comparison', far from establishing groupings of genetically related languages, is only a necessary first step taken before serious historical linguistic work begins. Greenberg actually stops where historical linguistic work begins (Campbell 1988, Kaufman 1990). 
We are going to concentrate ourselves on the proposal for grouping Tikúna within a larger group, called Macro-Tucanoan, and on the data offered to support such a claim. Until now, several articles have been written which scrutinize the data, rather than the methodology, on which Greenberg's work was based and upon which the claims for the genetic affiliation of particular languages are supposedly based (cf. Adelaar 1989, Kimball 1992, Poser 1992). As far as we know, no similar work has been done as it concerns Tikúna or Macro-Tucanoan as a whole.

Greenberg grouped Tikúna within a larger group that he called MacroTucanoan (1987:93). The other members of the group are: Auake, Auixiri, Canichana, Capixaná [Kanoê], Catuquina [Katukina], Gamella, Huari, Iranshe, Kaliana, Koaia, Maku [Máku], Mobima [Movima], Muniche, Nambikwara, Natu, Pankararu, Puinave [Makú], Shukuru, Tucano, Uman and Yurí. Data on Tikúna figure in 26 out of the 107 exclusively MacroTucanoan "etymologies" presented by Greenberg (1987:93-99). Of the 85 Macro-Tucanoan entries in his Amerind "etymological" dictionary, 23 contain Tikúna items (1987:181-270). There is no explicit indication of the sources on the Tikúna data used by Greenberg.

Tikúna was grouped in a subgroup along with Yurí within the larger Macro-Tucanoan group. Though Greenberg's classification is probably correct if it is taken as a mere recognition of the fact that no other language seems to be as similar to Tikúna as Yurí is (and so, in a sense, it may constitute a step forward as it concerns the evaluation of the Yurí-Tikúna hypothesis) there are obvious problems with the evaluation of this hypothesis as it is presented by Greenberg.

Setting aside the general problems with the low-quality and scarcity of the available data on Yurí and inherent limitations of a broad-scale classification project such as Greenberg's, there are indications that Greenberg's take on this data wasn't careful enough. Even though poor morphological segmentation is a recurrent feature of such documents, especially in the domain of 'relative nouns' (cf. Rodríguez 1996:604), Martius (1867:268) recognizes an independent formative as the prefixal marker for first-person possession in Yurí: "Tschu, was "Ich" heisst, spielt auch als Pronomen Possessivum praefixum eine Rolle" (Martius 1867:268).

This formative is clearly similar to the first-person markers $|t f a-|,|t f i|$ and $/ t f o /$ for first-person in Tikúna, not only in form, but also in its role as a prefix to nouns and to verbs. This evidence is overlooked by Greenberg 
when he comments on the grammatical evidence for his proposed groupings (1987:277). He only mentions the "close resemblance" involving the firstperson plural marker, which is too in Yurí and to in Tikúna, according to his data. Also overlooked is the somewhat less impressive but still significant similarity between the Yurí second-person pronoun wiku given by Martius (1867:271) and the second-person markers /ki-/and /ku-/in Tikúna. We have then the following similarities in pronoun forms not explicitly taken into account by Greenberg:

\begin{tabular}{|c|c|c|}
\hline & Tikúna & Yurí \\
\hline $1^{\circ} \mathrm{P} . \mathrm{Sg}$. & $\mathrm{t} \int \mathrm{a}-, \mathrm{t} \int \mathrm{o}-, \mathrm{t} \int \mathrm{i}-$ & tscho-, tschu-, tschä-, tschö- \\
\hline $2^{\circ}$ P. Sg. & ki-, ku- & wikú \\
\hline $1^{\circ} \mathbf{P} . \mathbf{P l}$. & ta, ti, to & too \\
\hline
\end{tabular}

To the forms above we can also add the third-person singular form of Yurí, given by Martius as nyi and meaning "he" (ille), which has a possible cognate in the Tikúna forms [ $n i-m a]$ and [ni-] both with a third person singular meaning. It is interesting to note at this point that even though Greenberg's claim that a second-person pronoun form with $k$ - constitutes strong grammatical evidence for the affinity of some of his groupings (1987:278) is really deceptive (Campbell 1988:602), the above-noted similarities in all pronominal forms for Tikúna and Yurí constitutes strong evidence for genetic relationship. These pronoun forms also display the correspondences we observed for the lexical material presented in section 3.2.2. and are quite different from those given by Tastevin (1921) to the Urí language.

So, it seems that even Greenberg, who recognized a Yurí-Tikúna relation, didn't state the hypothesis in its full force and didn't subject the Yurí data to adequate scrutiny. This latter conclusion is startling since, as Loukotka did earlier, Greenberg took his Yurí data from the same list given in Martius (1867) from which we sample the list of possible cognates with Tikúna presented in section 3.2.2., as well as the pronoun forms, which when looked at with greater care seem to make the case for a Yurí-Tikúna connection even more solid. That this should be so isn't surprising, given the evaluations of Greenberg's methods as "heuristic practice" and that "Similarities unearthed by it must still be evaluated against standard criteria." (Campbell 1988:597).

\section{Last Remarks, Synthesis and Conclusions}

The Tikúna language has been proposed to have linguistic relations of different sorts with distinct groups and languages. Some of these claims have not been advanced with the relevant evidence presented in an explicit and 
systematic manner. The existence of Pano and Tukano elements in Tikúna, for example, fit into this category.

Some hypotheses have been discussed with at least an incipient handling of data, among these the claims of a genetic relation of Tikúna with Arawák and the hypotheses suggesting the existence of Jê and Tupí elements in the Tikúna lexicon. We have given especial attention to the hypothesis suggesting the existence of "Jê elements in Tikúna" or "Jê-Tikúna resemblances", not subject to adequate scrutiny elsewhere in the literature. We have concluded that the similarities between Jê languages and Tikúna pointed out in the literature are probably fortuitous and accidental in nature.

The most promising claim for the genetic affiliation of Tikúna with another language or linguistic family to be found in the literature is the YuríTikúna hypothesis, that is, the claim that Tikúna is genetically related to the extinct Yurí language, known to us through a few wordlists collected in the XIX century. Though deemed in the literature as a relatively sensible hypothesis of genetic affiliation, the Yurí-Tikúna hypothesis has never been subject to a systematic investigation. We conclude from what was presented here in sections 3.2.2. and 3.4., that the strength of this hypothesis has been actually understated. Even if we concede the many difficulties attending any handling of such poorly transcribed data as the Yurí wordlist given by Martius, a systematic presentation of the word forms that are likely cognates, including the pronoun forms in both languages, shows that a higher probability can be assigned to this hypothesis being true than previously thought.

A final word regarding a recent attempt at the genetic classification of Tikúna should be added. Jolkesky (2009) proposes that Tikúna is related to the languages Sáliba, Piaroa, Hoti and Andoke, forming a group for which he proposes the name Macro-Daha. The author presents a comparison of lexical material, grammatical markers, as well as some structural and typological similarities obtaining among those languages.

We have avoided in the present paper a closer scrutiny of the Jolkesky (2009) study as it does not take into consideration the relation between Tikúna and Yurí, the main concern of our paper.

\section{References}

Adelaar, W. F. H. 1989. Review of Language in the Americas, by Joseph H.

Greenberg. Lingua 78:249-255. 
Aikhenvald, A. 1999. Arawak. In: R. W. M. Dixon \& A. Aikhenvald (orgs.) The Amazonian Languages. Cambridge: Cambridge University Press, 65-106.

Alviano, Frei F. de.1944. Gramática, dicionário, verbos e frases e vocabulário prático da língua dos Índios Ticunas. Revista do Instituto Histórico e Geográfico Brasileiro, vol. 183:1-194.

Anderson, L. 1958. Vocabulario breve del idioma ticuna. Tradición: Revista Peruana de Cultura, VIII.21:1-18.

Anderson, L. 1959. Ticuna vowels with special regard for the system of five tonemes. In: Linguística Especial 1:76-119. Rio de Janeiro: Museu Nacional.

Cabral, A. S. A. 1995. Contact-induced language change in the Western Amazon: the non-genetic origin of the Kokáma language. Doctoral Dissertation, University of Pittsburgh.

Campbell, L. 1988. Review of Language in the Americas by Joseph H. Greenberg. Language 64:591-615.

Campbell, L. 1997. American Indian Languages: the historical linguistics of native America. Oxford: Oxford University Press.

Davis, I. 1966. Comparative Jê phonology. Estudos Linguísticos: Revista Brasileira de Linguística Teórica e Aplicada 1(2):10-24.

Jolkesky, M. (2009). Macro-Daha: reconstrução de um tronco linguístico do noroeste amazônico. Communication presented at the I Congresso Internacional de Linguística Histórica (ROSAE), Salvador (Bahia).

Kaufman, T. 1990. Language history in South America: what we know and how to know more. In: Doris L. Payne (ed.), Amazonian linguistics: studies in lowland South American languages. Austin: University of Texas Press, 13-73.

Kimball, G. 1992. A critique of Muskogean, "Gulf," and Yukian material in Language in the Americas. IJAL 58:447-501.

Krieger, W. \& G. Krieger. 1994. Dicionário escolar Xerente-Português, Português-Xerente. Rio de Janeiro: Junta de Missões Nacionais da Convenção Batista Brasileira.

Loukotka, C. 1968. Classification of South American Indian languages. Los Angeles: University of California Press.

Lowe, I. 1960. Tikuna phonemics (ms.). Summer Institute of Linguistics. Acervo do CELIN, Museu Nacional, Rio de Janeiro.

Maddieson, I. 2005. Tone. In: M. Haspelmath, M. Dryer, D. Gil \& B. Comrie (orgs.), The world atlas of language structures. Oxford University Press, 58-61.

Malone, T. 1987. Proto-Tucanoan and Tucanoan genetic relationships. Instituto Linguistico de Verano, Colombia. 
Martins, S.; V. Martins, 1999. Makú. In: R. M. W. Dixon \& A. Aikhenvald (orgs.), The Amazonian languages. Cambridge University Press, 251-267.

Martius, K. P. F. von. 1867. Beiträge zur Ethnographie und Sprachenkunde Amerikas, zumal Brasiliens. Leipzig: Fleischer.

Matisoff, J. 1975. Rhinoglottophilia: the mysterious connection between nasality and glottality. In: C. Ferguson, L. Hyman \& J. Ohala (orgs.), Nasalfest: Papers from a Symposium on nasals and nasalization. Universals of Language Project, Stanford University, 265-287.

Matisoff, J. 1990. On megalo-comparison: a discussion note. Language 66:106120.

Matisoff, J. 1999. Tibeto-Burman tonology in an areal context. In: S. Kaji (org.) Cross-Linguistic Studies of Tonal Phenomena: Tonogenesis, Typology and Related Topics. Institute for the Study of Languages and Cultures of Asia and Africa (ILCAA). Tokyo University of Foreign Studies, 3-32.

McQuown, N. 1955. Indigenous languages of Latin America. American Anthropologist 57(3):501-570.

Mountain, K. 1978. Lista de palabras Swadesh y Rowe. In: M. Anderson \& B. Anderson (orgs.), Artículos en Linguística y Campos Afines 4. Instituto Linguistico de Verano, Colômbia, 1-57.

Nettle, D. 1999. Linguistic diversity of the Americas can be reconciled with a recent colonization. Proceedings of the National Academy of Sciences of the USA 96:3325-3329.

Nimuendajú, C. 1929. Wortliste der Tukuna-Sprache (ms.). Belém do Pará. Acervo do CELIN: Museu Nacional, Rio de Janeiro.

Nimuendajú, C. 1952. The Tukuna. University of California Press.

Poser, W. J. 1992. The Salinan and Yurumanguí data in Language in the Americas. IJAL 24:174-188.

Ramirez, H. 2001. Linguas Arawak da Amazônia setentrional: comparação e descrição. Universidade do Amazonas.

Rankin, R. L. 1992. Review of Language in the Americas by Joseph H. Greenberg. IJAL 58:324-351.

Rivet, P. 1912. Affinités du Ticuna. Journal de la Societé des Américanistes de Paris 9:83-110.

Rodrigues, A. D. 1986. Linguas brasileiras: para o conhecimento das linguas indigenas. São Paulo: Loyola.

Rodrigues, A. D. 1999. Macro-Jê. In: R. M. W. Dixon \& A. Aikhenvald (orgs.), The Amazonian languages. Cambridge University Press, 165-206. 
Rodríguez, M. E. 1995. Tonología de la lengua Ticuna. Lenguas Aborígenes de Colombia, Descripciones 9. Bogotá: Universidad de los Andes.

Rodríguez, M. E. 2004. Morfosintaxis de la lengua Tikuna. Lenguas Aborígenes de Colombia 15. Bogotá: Universidad de Los Andes

Soares, M. F. 1984. Traços acústicos das vogais em Tukuna. Cadernos de Estudos Linguísticos 7:137-175.

Soares, M. F. 1986. Alguns processos fonológicos em Tükuna. Cadernos de Estudos Linguísticos 10:97-138.

Soares, M. F. 1992. O suprasegmental em Tikuna e a teoria fonológica, v.I: Investigação de Aspectos da Sintaxe Tikuna. Campinas: Editora da UNICAMP.

Soares, M. F. 1995. Núcleo e Coda. A Sílaba em Tikuna. In: Wetzels, L. (org.), Estudos Fonológicos das Línguas Indígenas Brasileiras. Rio de Janeiro: Editora da UFRJ, p.194-263.

Soares, M. F. 1998. Sous-spécification tonale em Tikuna. In: Caron, B. (org.), Actes du 16e Congrès de Linguistes. Oxford: Elsevier Sciences, 14 p.

Tastevin, C. 1921. Yucuna-Uri-Ticuna. In: Landaburu, J. (org.) Documentos sobre Lenguas Aborigenes de Colombia del Archivo de Paul Rivet, v.I: Lenguas de la Amazonia Colombiana. Universidad de los Andes, 1996, 359-483.

Tessmann, G. 1930. Die Indianer Nordost-Perus: Grundlegende Forschungen für eine systematische Kulturkunde. Hamburg: Friederichsen, de Gruyter \& Co.

Thiessen, W. 1996. Gramática del idioma Bora. Instituto Linguistico de Verano: Serie Linguistica Peruana, 38.

Voegelin, C.; F. Voegelin. 1965. Languages of the World: Native America Fascicle two. Anthropological Linguistics 7 (7):1-150.

Wallace, A. R. 1853. A Narrative of Travels on the Amazon and Rio Negro.

Walton, J.; J. Walton. 1967. Phonemes of Muinane. In: V. Waterhouse (org.), Phonemic systems of Colombian languages. SIL Publications in Linguistics 14:37-47.

Wise, M. R. 1999. Small language families and isolates in Peru. In: Dixon, R.; A. Aikhenvald (orgs.), The Amazonian Languages. Cambridge University Press, 307-340. 